\title{
Tobacco Plants Transformed with a Modified Coat Protein of Tomato Mottle Begomovirus Show Resistance to Virus Infection
}

\author{
X. H. Sinisterra, J. E. Polston, A. M. Abouzid, and E. Hiebert
}

First and second authors: Department of Plant Pathology, University of Florida, Gulf Coast Research and Education Center, 5007 60th Street E., Bradenton 34203-9324; and third and fourth authors: Department of Plant Pathology, University of Florida, Gainesville 32611-0680. Accepted for publication 4 May 1999.

\begin{abstract}
Sinisterra, X. H., Polston, J. E., Abouzid, A. M., and Hiebert, E. 1999. Tobacco plants transformed with a modified coat protein of tomato mottle begomovirus show resistance to virus infection. Phytopathology 89:701706.

Tobacco plants (Nicotiana tabacum 'Xanthi') were transformed with a binary vector containing the coat protein gene of tomato mottle begomovirus (ToMoV) modified by the deletion of 30 nucleotides in the $5^{\prime}$ end. The $\mathrm{R}_{1}$ generation was screened for resistance to ToMoV by inoculation

and $\mathrm{ToMoV}$ infection was confirmed by polymerase chain reaction and enzyme-linked immunosorbent assay. The response to high inoculation levels of ToMoV varied and ranged from susceptibility to immunity. The transgene transcript was detected by northern blot analysis; however, the transgene product could not be detected by protein blot analysis using antisera reactive with ToMoV coat protein. The lack of detection of the transgene product in resistant plants suggests that it is not involved in eliciting the resistance response and that resistance may be mediated by the transgene transcript.
\end{abstract} with viruliferous whiteflies. Fifteen days after inoculation, symptom development was recorded weekly for up to 120 days using a visual scale,
Additional keywords: Bemisia tabaci, pathogen-derived resistance.
Begomoviruses have a single-stranded DNA genome arranged in two circular components. Component $\mathrm{A}$ encodes the coat protein gene $(A V 1)$ and the genes involved in the replication process ( $A C 1, A C 2$, and $A C 3$ ); component $\mathrm{B}$ encodes two movement genes $(B V 1$ and $B C 1$ ). The geminivirus coat protein plays a role in protection of the genome from degradation, virus acquisition and transmission by insect vectors, infectivity, and systemic movement (18). The coat protein is the determinant of the specificity of virus transmission (5) and, in some virus-host systems, appears to be associated with symptom development (11). It has also been proposed that the coat protein is necessary for the systemic movement of bipartite geminiviruses in hosts in which the virus is not well adapted (27).

Tomato mottle virus (ToMoV) is a typical whitefly-transmitted begomovirus of the New World. ToMoV was first identified in Florida in 1989 and, since then, has been found in all tomato production areas in Florida at incidences as high as $95 \%$ and caused losses estimated at $\$ 125$ million in the south Florida production area for the 1990-1991 crop season $(15,25)$. Because of the lack of tolerant or resistant cultivars, control measurements have been primarily focused on controlling the vector Bemisia tabaci (Gennadius) by contact or systemic insecticides, with the concomitant problems of development of insecticide resistance, low cost-benefit ratios, and multiple environmental concerns (25).

Pathogen-derived resistance, as defined by Sanford and Johnson (30), is a strategy in which entire genes or sequences of the pathogen genome (both structural and functional) are used to transform host plants so that protection against the particular pathogen or a range of closely related pathogens is achieved. The success of this approach has largely been in its application to RNA viruses $(2,21)$. The coat protein gene, in particular, has been used extensively to engineer resistance to potex-, poty-, tobamo-, cucumo-, tobra-, carla-,

Corresponding author: J. E. Polston; E-mail address: jep@ @ersp.nerdc.ufl.edu

Publication no. P-1999-0607-02R

(c) 1999 The American Phytopathological Society and luteoviruses (3); however, there are fewer reports of engineered resistance to geminiviruses. Success has been reported with expression of geminivirus transgenes of modified and unmodified coat protein $(A V 1)$, replication-associated protein (Rep), and movement protein genes $(4,10,13,16,23)$. In some studies, resistance was conferred by transgene expression and accumulation of the product, whereas in other cases, resistance was reported to be due to a dominant negative mutation. The use of antisense $A C l$ genes has been shown to confer resistance to tomato golden mosaic virus and tomato yellow leaf curl virus (TYLCV) $(4,8)$.

Here, we report that transgenic tobacco plants, transformed with a modified ToMoV coat protein gene, exhibit resistance to viral infection and that this response may be associated with the posttranscriptional processing of transgene mRNA.

\section{MATERIALS AND METHODS}

Plant transformation. Tobacco plants (Nicotiana tabacum 'Xanthi') were transformed using standard Agrobacterium-mediated techniques (14) with a cassette containing the ToMoV coat protein sequence, truncated by 30 nucleotides in the $5^{\prime}$ end, under the control of the cauliflower mosaic virus (CaMV) $35 \mathrm{~S}$ promoter and the cucumber mosaic virus (CMV) coat protein $5^{\prime}$-untranslated leader sequence, which provides a start codon for the expression of the modified ToMoV coat protein open reading frame (ORF) (Fig. 1). The following partial sequence of the transformation cassette shows the CMV leader sequence (underlined nucleotides), the start codon (lowercase nucleotides), and 51 nucleotides of the $5^{\prime}$ end of the truncated ToMoV coat protein gene: GTTTAGTTGTTCACCTGAGTCGTGTGTTTTGTATTTTGCGTCTTATTGTGCCatgGATG CTAATTATTCTCCCCGAATAACAAGGCCGCTGAATGGGTG AACCGGCC. This construct was ligated into plasmid pBI121 (Clontech Labs Inc., Palo Alto, CA), a plant constitutive expression vector containing the neomycinphospho-transferase II gene for selection and the $\beta$-glucuronidase reporter gene (1).

Plant inoculation and disease scoring. ToMoV was obtained from a culture maintained in tomato. It was transmitted to tobacco 
plants by whiteflies and then was maintained in tobacco. Whiteflies were reared on the ToMoV-infected tobacco plants for a minimum of two generations. Whiteflies and virus-infected plants were maintained in an insect-rearing room $\left(25^{\circ} \mathrm{C}, 16\right.$-h photoperiod $)$ at the Gulf Coast Research and Education Center, Bradenton, FL.

Transgenic and nontransformed tobacco seedlings ( N. tabacum 'Xanthi') at the seven- to nine-leaf stage were exposed to viruliferous whiteflies (B. tabaci) by confinement in cages for 15 days, using about 20 whiteflies per plant. The whiteflies used in this study originated from a colony identified by isozyme analysis (26) as the B biotype of $B$. tabaci.

Fifteen days after inoculation and weekly thereafter for 120 days, disease severity was evaluated using visual assessment and a rating scale of 0 to 4 , in which $0=$ no symptoms observed; $1=$ light mottling and a few thin yellow veins; $2=$ mottling and vein clearing unevenly distributed on the leaf; $3=$ mottling, leaf distortion, and stunting; and $4=$ severe mottling, leaf curling, and stunting. Onset of symptom expression as well as disease severity was recorded for each plant.

Detection of ToMoV and the transgene. The presence of the viral DNA in the inoculated plants was determined by polymerase chain reaction (PCR) amplification using primers EH $287\left(5^{\prime}-\right.$ GCCTTCTCAAACTTGCTCATTCAAT-3') and EH 288 (5'-GTTCGCAACAAACAGAGTGTAT-3') designed to encompass the 5' and $3^{\prime}$ ends, respectively, of the ToMoV coat protein ORF. Reactions were run for three cycles of $95^{\circ} \mathrm{C}$ for $3 \mathrm{~min}, 55^{\circ} \mathrm{C}$ for $2 \mathrm{~min}$, and $72^{\circ} \mathrm{C}$ for $4 \mathrm{~min}$, followed by 34 cycles of $95^{\circ} \mathrm{C}$ for $2 \mathrm{~min}$, $55^{\circ} \mathrm{C}$ for $1 \mathrm{~min}$, and $72^{\circ} \mathrm{C}$ for $3 \mathrm{~min} 45 \mathrm{~s}$. The annealing temperature duration was decreased $1 \mathrm{~s}$ in every cycle.

Successful transformation was confirmed by PCR amplification using primers JAP 28 (5'-GATAGTGGAAAAGGAAGG-3') and JAP 82 (5'-CCTTACCGATATGTGA-3'), which bind to the CaMV $35 \mathrm{~S}$ promoter and the ToMoV coat protein gene coding region, respectively. Amplification was carried out for 34 cycles of $94^{\circ} \mathrm{C}$ for $1 \mathrm{~min}, 50^{\circ} \mathrm{C}$ for $1 \mathrm{~min}$, and $72^{\circ} \mathrm{C}$ for $3 \mathrm{~min}$, with a final elongation of $72^{\circ} \mathrm{C}$ for $5 \mathrm{~min}$.

Enzyme-linked immunosorbent assay (ELISA). ELISA for ToMoV detection in tobacco leaf extracts was carried out with the triple-sandwich method as described by Cancino et al. (6). ELISA plate wells were coated with polyclonal antiserum 1110 (1:1,000). After the incubation of plant samples, the 3F7 monoclonal antibody $(1: 10,000)$ was added to the wells, and the plates were incu-

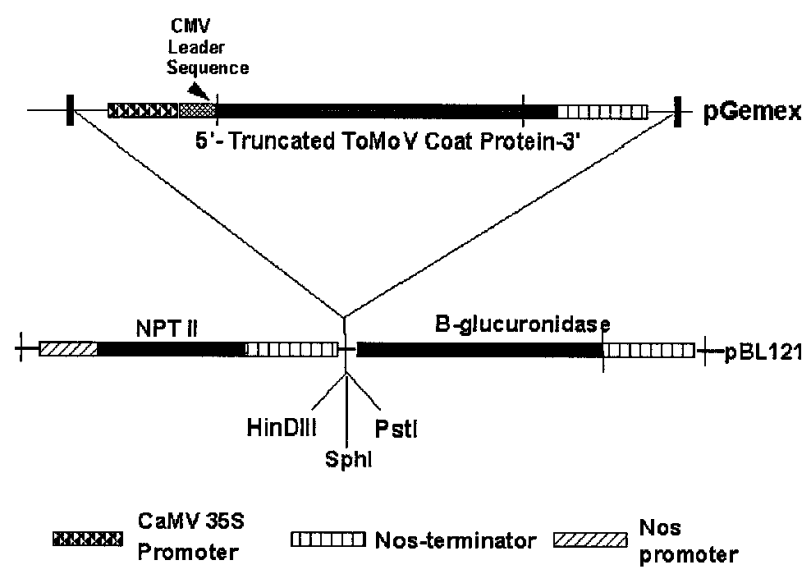

Fig. 1. Transformation cassette used to transform tobacco plants (Nicotiana tabacum 'Xanthi'). The coat protein sequence was cut out of a clone of the tomato mottle virus A component using restriction enzymes $N c o \mathrm{I}$ and $\mathrm{Xba \textrm {I }}$. The ligation of cucumber mosaic virus (CMV) coat protein leader sequence provides a start codon for the expression of the modified tomato mottle virus (ToMoV) coat protein open reading frame. The construct was ligated into plasmid pBI121 (Clontech Labs Inc., Palo Alto, CA), which contains the cauliflower mosaic virus (CaMV) 35S gene promoter, the neomycinphospho-transferase II gene for selection, and the reporter gene $\beta$-glucuronidase. bated overnight at $4{ }^{\circ} \mathrm{C}$. Goat anti-mouse immunoglobulin $\mathrm{G}$ (IgG) conjugated with alkaline phosphatase (Sigma Chemical Co., St. Louis) $(1: 30,000)$ was then added to the wells, and the plates were incubated for $1 \mathrm{~h}$ and washed three times. Absorbance readings $(405 \mathrm{~nm})$ were taken on a Biotek EL 309 automated microplate reader (BioTek Instruments, Inc., Winooski, VT) every $30 \mathrm{~min}$ for $2 \mathrm{~h}$.

DNA and RNA extraction. Plant genomic DNA to be used in the Southern blot procedure was isolated by a modification of the method of Cocciolone and Cone (7). Tissue from newly emerged leaves $(0.2 \mathrm{~g})$ was ground in liquid nitrogen with $1 \mathrm{ml}$ of extraction buffer (7 M urea; $0.35 \mathrm{M} \mathrm{NaCl} ; 50 \mathrm{mM}$ Tris, $\mathrm{pH}$ 8.0; $20 \mathrm{mM}$ EDTA; and 1\% Sarkosyl). This extract was transferred to a 2-ml microcentrifuge tube and extracted 1:1 (vol/vol) with phenol/chloroform/isoamyl alcohol (25:24:1). After centrifugation at 3,000 $\times g$ for $5 \mathrm{~min}$, the supernatant was extracted $1: 1$ ( $\mathrm{vol} / \mathrm{vol}$ ) with chloroform/isoamyl alcohol (24:1) and centrifuged at 6,000 $\times g$ for $5 \mathrm{~min}$. An equal volume of isopropanol was added to the supernatant, and the mixture was kept at $-20^{\circ} \mathrm{C}$ for $1 \mathrm{~h}$. The DNA was precipitated by centrifugation at $16,000 \times g$ for $20 \mathrm{~min}$ and redissolved in TrisEDTA (10 mM Tris-HCl, pH 8.0, and $1 \mathrm{mM}$ EDTA) containing $0.5 \%$ Sarkosyl with $10 \mu \mathrm{g}$ of RNase. After $30 \mathrm{~min}$ of incubation at $37^{\circ} \mathrm{C}$, the mixture was extracted once with 1 volume of phenol/chloroform (1:1) and then with 1 volume of chloroform. DNA was reprecipitated with 0.1 volume of $3 \mathrm{M}$ sodium acetate and 2.5 volumes of $100 \%$ ethanol. DNA samples were dissolved in RNase and DNasefree water (molecular grade water) and stored at $-20^{\circ} \mathrm{C}$.

Total RNA to be used in the northern blots was isolated by a modification of the Cocciolone and Cone (7) method. Samples were prepared and extracted as above until just before the isopropanol addition. After the addition of an equal volume of isopropanol and chilling on ice for $5 \mathrm{~min}$, a DNA precipitate was formed. The soluble fraction containing the RNA was decanted into a $1.5-\mathrm{ml}$ Eppendorf tube and chilled at $-20^{\circ} \mathrm{C}$ for $1 \mathrm{~h}$. The RNA was precipitated by centrifugation at $16,000 \times g$ for $10 \mathrm{~min}$. The pellet was washed with $70 \%$ ethanol and dissolved in molecular biology grade water.

DNA and RNA blot analyses. Ten micrograms of genomic DNA from $\mathrm{R}_{1}$ plants was digested overnight at $37^{\circ} \mathrm{C}$ with restriction enzymes EcoRI, which cuts outside of the transgene, and $X b a \mathrm{I}$, which cuts at the $3^{\prime}$ end of the transgene. The digested DNA was separated by electrophoresis on $0.75 \%$ agarose and transferred to nylon membrane with alkaline transfer buffer, and the

TABLE 1. Response of $\mathrm{R}_{1}$ generation Nicotiana tabacum plants transformed with a modified coat protein gene of tomato mottle virus (ToMoV) at 120 days after inoculation

\begin{tabular}{lccc}
\hline Germ plasm line $^{\mathrm{x}}$ & $\begin{array}{c}\text { Number of } \\
\text { plants evaluated }\end{array}$ & $\begin{array}{c}\text { Number of plants } \\
\text { with transgene }\end{array}$ & $\begin{array}{c}\text { Number of } \\
\text { resistant plants }\end{array}$ \\
\hline $\mathrm{R}_{1}$-cp 2 & 12 & 4 & 1 \\
$\mathrm{R}_{1}$-cp 4 & 12 & 5 & 1 \\
$\mathrm{R}_{1}$-cp 5 & 12 & 7 & 1 \\
$\mathrm{R}_{1}$-cp 6 & 24 & 24 & 15 \\
$\mathrm{R}_{1}$-cp 7 & 12 & 3 & 0 \\
$\mathrm{R}_{1}$ cp 8 & 12 & 3 & 2 \\
$\mathrm{R}_{1}$-cp 9 & 12 & 6 & 1 \\
$\mathrm{R}_{1}$-cp 10 & 12 & 4 & 4 \\
$\mathrm{R}_{1}$-cp 11 & 24 & 6 & 3 \\
$\mathrm{R}_{1}$-cp 12 & 24 & 3 & 0 \\
Nontransformed & 34 & 0 & 3 \\
\hline
\end{tabular}

${ }^{x}$ Plants were inoculated with ToMoV using viruliferous whiteflies. The results for lines $R_{1}$-cp $6, R_{1}$-cp 11 , and $R_{1}$-cp 12 summarize two independent inoculations. The efficiency of the inoculation was 100 and $91.6 \%$, respectively.

y Presence of the transgene was confirmed by polymerase chain reaction (PCR) amplification using primers complementary to sequences in the cauliflower mosaic virus $35 \mathrm{~S}$ promoter and ToMoV coat protein gene coding region.

${ }^{\mathrm{z}}$ Resistant plants were those that displayed the recovery or immune phenotype. ToMoV infection was determined by enzyme-linked immunosorbent assay and PCR amplification with primers corresponding to complementary sequences in the $5^{\prime}$ and $3^{\prime}$ ends of the ToMoV coat protein gene. 
membrane was UV-crosslinked while damp. The probe was made by random primer labeling of the PCR product generated with primers JAP 28 and JAP 82, which contains the partial CaMV 35S promoter sequence, the CMV leader region sequence, and about 170 nucleotides of the $5^{\prime}$ end of the ToMoV coat protein sequence, using a nonradioactive random octamer labeling system (Tropix, Inc., Bedford, MA). The hybridization was performed overnight at $65^{\circ} \mathrm{C}$ in a hybridization buffer containing $1 \mathrm{mM}$ EDTA, $7 \%$ sodium dodecyl sulfate (SDS), and $0.25 \mathrm{M}$ disodium phosphate, $\mathrm{pH} 7.2$, followed by a high stringency wash and detection of the biotinylated DNA using Tropix chemiluminescence detection system (Tropix, Inc.).

Ten to fifteen micrograms of total RNA was separated on a $1.0 \%$ agarose gel with formaldehyde, blotted onto a nylon membrane (Bioblot-N Plus; Costar Scientific Corp., Cambridge, MA), and hybridized with the full-length ToMoV coat protein gene DNA fragment generated by PCR amplification and labeled with biotin using the Tropix nonradioactive random octamer labeling system (Tropix, Inc.). The detection protocol was the same as that used for Southern blots.

Protein blots. The subcellular fractions of the leaf extracts from transgenic and nontransgenic control tobacco plants were prepared as described by Pascal et al. (24). The proteins were separated by SDS-polyacrylamide gel electrophoresis in a discontinuous Laemmli system (5.6\% acrylamide stacking gel and 10\% acrylamide separation gel). The separated proteins were electrotransferred onto a nitrocellulose membrane (Bio-Rad Laboratories, Hercules, CA) and detected with mouse monoclonal 3F7 made against a mixture of purified virions of bean golden mosaic virus isolates from Guatemala and the Dominican Republic, which efficiently recognizes ToMoV (6), and rabbit polyclonal antiserum 1175 . The polyclonal antiserum was made against the truncated ToMoV coat protein, expressed in Escherichia coli, using the same coat protein construct that was used to transform the tobacco plants in this study (A. M. Abouzid, J. E. Polston, K. Beckam, W. E. Crawford, M. A. Peterson, B. Peyser, and E. Hiebert, unpublished data). The immunoreaction was detected by adding anti-mouse IgG alkaline phosphatase and anti-rabbit IgG alkaline phosphatase conjugates, respectively, and the enzyme substrate NBT/BCIP (Life Technologies, Princeton, NJ).

\section{RESULTS}

Detection of the transgene. The presence of the modified coat protein gene was detected by PCR in different frequencies among lines in the $R_{1}$ generation (Table 1 ). The lowest frequency occurred in line $R_{1}$-cp $12(12.5 \%)$ and the highest occurred in line $R_{1}-c p 6$ $(100 \%)$

Response to virus inoculation. The results of two separate inoculations with ToMoV of the $\mathrm{R}_{1}$ generation of the tobacco plants (N. tabacum 'Xanthi') transformed with the modified ToMoV coat protein gene are summarized in Table 1 . In the first inoculation, 12 plants of the $\mathrm{R}_{1}$ generation from each of $10 \mathrm{R}_{0}$ tobacco plants and 22 nontransformed plants were used. In the second inoculation, 12 plants of lines $\mathrm{R}_{1}$-cp $6, \mathrm{R}_{1}$-cp 11 , and $\mathrm{R}_{1}$-cp 12 and 12 nontransformed control plants were used.
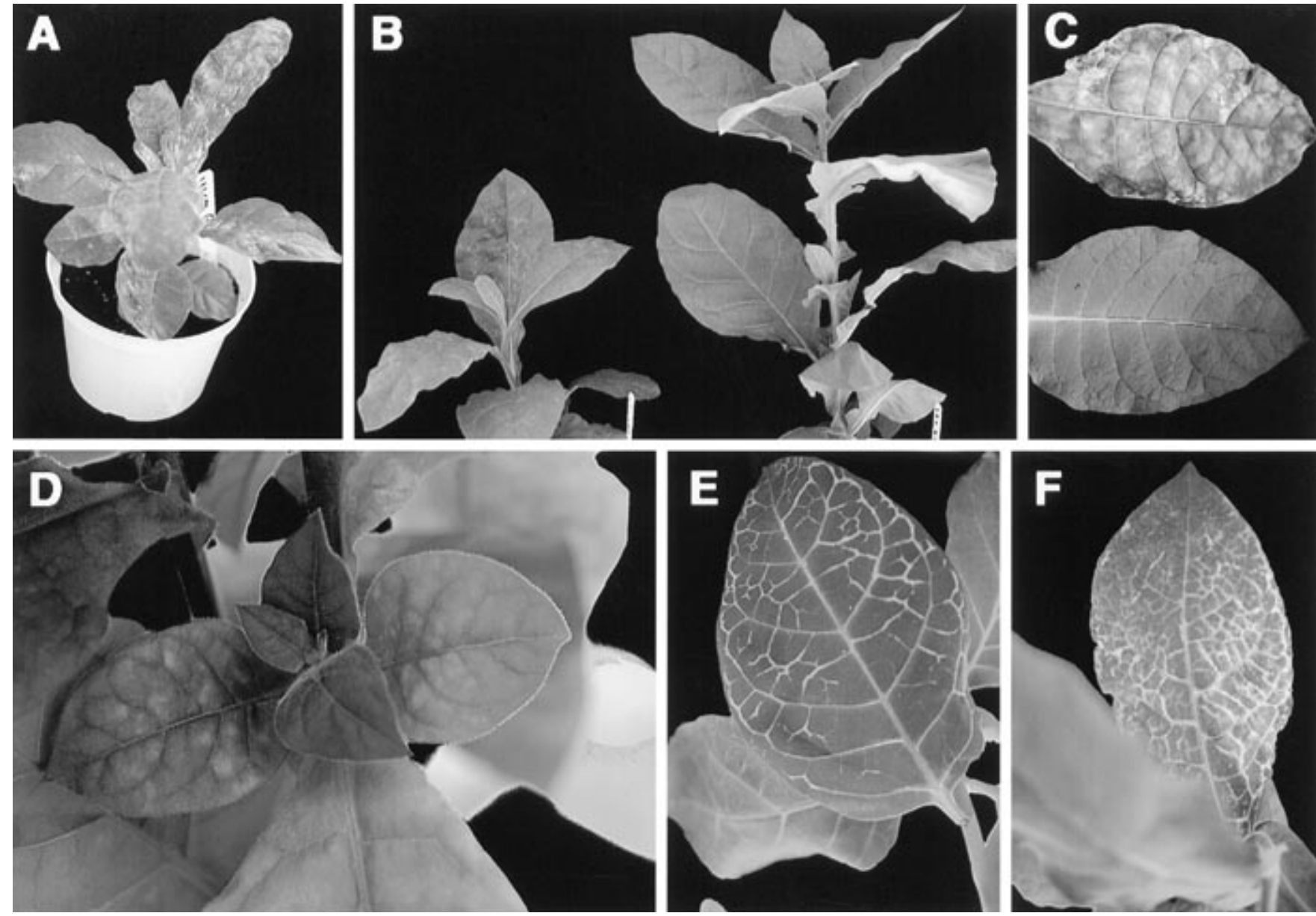

Fig. 2. Response of transgenic tobacco plants to inoculation with tomato mottle virus (ToMoV). A, Symptom level 4 in a transgenic plant. B, Nontransgenic control (left) showing mottling and stunting (rating = 3) compared with a resistant transgenic plant (right) at 120 days after inoculation (dai). C, Detached leaf of a nontransgenic control plant (top) showing severe mottling (rating =4) compared with a leaf of a resistant transgenic plant (bottom) at 120 dai. D, Recovery phenotype of inoculated leaves showing mottling (rating = 3) contrasting with the newly formed and asymptomatic leaves on the same plant. E and F, Severe yellowing of the veins (symptom not rated) found only in transgenic plants. 
In the first inoculation, all 22 nontransgenic plants were infected by 15 days after inoculation (dai), as determined by PCR amplification. A range of symptom severity was observed; 10 plants had a symptom severity rating of 1 (light mottling and thin yellow veins), another 10 plants had a rating of 2 (mottling and vein clearing unevenly distributed on the leaf), and 1 plant had a rating of 3 (mottling, leaf distortion, thick yellow veins, and stunting). By 30 dai, all nontransgenic plants had a symptom severity rating of 3 .

Differences in responses to ToMoV inoculation between transformed and nontransformed plants were apparent as early as 15 dai. The response of plants in which the transgene was present varied among plants and over time. At 15 dai, 21 plants had a symptom severity rating of 0,32 plants had a rating of 1,26 plants had a rating of 2, and 5 plants had a rating of 3 . ToMoV was detected, using PCR amplification, in all transformed plants displaying symptoms and in 10 of the 21 asymptomatic plants.

At 30 dai, a wild-type phenotype consisting of mottling, leaf distortion, and stunting (symptoms observed in ToMoV-infected nontransgenic tobacco) was observed in 18 transformed plants. In addition, a recovery phenotype was observed in 11 plants from line $R_{1}-c p 6$. These plants had a symptom rating of 1 at 15 dai, but by 30 dai, had a rating of 0 . These plants remained asymptomatic until the end of the experiment (120 dai). ToMoV was detected in the symptomatic leaves of the 11 plants using PCR amplification at 15 dai; however, ToMoV was not detected in the asymptomatic leaves of any of these plants using either PCR amplification or ELISA at 30, 60, and 120 dai.

At 60 dai, six distinct phenotypes (wild type, enhanced wild type, bright vein yellowing, delay in symptom expression, recovery, and immunity) could be observed in plants in which the transgene was present (Fig. 2). Plants that displayed the wild-type phenotype (a rating of 3 ) were found at low frequencies in all lines (Fig. 2A). Plants that displayed an enhanced wild-type phenotype (severe mottling, leaf curling, and stunting) had a rating of 4 and were found at low frequencies in lines $\mathrm{R}_{1}$-cp $4, \mathrm{R}_{1}$-cp $5, \mathrm{R}_{1}$-cp 7 , and $\mathrm{R}_{1}$-cp 12. Plants with the bright vein yellowing phenotype had a rating of 1 at 15 and 30 dai, but by 60 dai, displayed an unusual pattern of thick yellow veins that fell outside the rating scale (Fig. 2E and F). This phenotype was not observed in noninoculated transformed plants or in ToMoV-infected nontransformed plants. ToMoV was detected in all plants exhibiting this phenotype. Plants with the delay in symptom expression phenotype had a rating of 0 at 15 dai, by 30 dai, had ratings of 1 and 2, and by 60 dai, had ratings of 2 , 3 , or 4 . This phenotype was observed in 10 plants in lines $R_{1}$-cp 8 , $\mathrm{R}_{1}$-cp 10 , and $\mathrm{R}_{1}$-cp 12 . The immunity phenotype was observed in 13 plants from all lines, except $\mathrm{R}_{1}$-cp 7 (Fig. $2 \mathrm{~B}$ and $\mathrm{C}$ ). Plants were considered immune when no symptoms were expressed up to 120 dai and ToMoV was not detected by either PCR amplification or ELISA at 30, 60, and 120 dai.

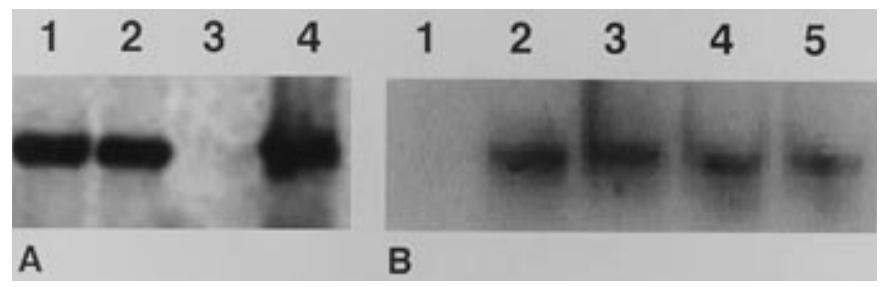

Fig. 3. Hybridization analysis of total RNA from selected resistant transgenic plants that did not show disease symptoms and tested negative for the presence of tomato mottle virus (ToMoV) by polymerase chain reaction with a biotin-labeled probe to the full-length ToMoV coat protein gene. A, Lane 1, virus-infected nontransgenic plant; lane 3, noninoculated, nontransformed plant; and lanes 2 and 4 , resistant plants of lines $\mathrm{R}_{1}$-cp 8 and $\mathrm{R}_{1}$-cp 11, respectively. $\mathbf{B}$, Lane 1 , noninoculated, nontransformed tobacco plant; lanes 2, 3, 4, and 5, selected resistant plants of lines $R_{1}-c p ~ 6$, $R_{1}$-cp $10, R_{1}$-cp 11 , and $R_{1}$-cp 12 , respectively, showing the presence of the transgene transcript.
In the second inoculation, 11 out of the 12 nontransgenic plants were infected at 15 dai. Four plants in line $R_{1}$-cp 6, two plants in line $R_{1}$-cp 11, and one plant in line $R_{1}$-cp 12 displayed an immune phenotype. The recovery and enhance wild-type phenotypes were not observed.

The recovery and immunity phenotypes were considered resistance responses. The transgenic lines showed different frequencies of resistance in plants in which the presence of the transgene was confirmed. Frequencies ranged from high $\left(100 \%\right.$ in lines $R_{1}$-cp 10 and $\left.R_{1}-c p 12\right)$, to moderate $\left(66.6 \%\right.$ in line $R_{1}-c p 8$ and $62.5 \%$ in line $R_{1}$-cp 6), to low (20 to $25 \%$ in lines $R_{1}$-cp $2, R_{1}$-cp 4, $R_{1}$-cp 5, and $\left.R_{1}-c p 11\right)$, to none (0\% in line $\left.R_{1}-c p 7\right)$ (Table 1$)$. At 120 dai, all plants displaying a resistance response tested negative for ToMoV by ELISA and PCR amplification.

Correlation between the presence of the modified ToMoV coat protein gene and the resistant phenotype. The modified coat protein gene was present in 12.5 to $100 \%$ of plants in each of the transformed lines (Table 1). Twenty percent of plants with the transgene exhibited a resistance response. The presence of the transgene was established in all plants that displayed a recovery or immune phenotype, as well as in those plants that displayed the unusual vein yellowing pattern.

Transgene copy number, level of transcription, and expression. Southern blot analysis of selected resistant plants revealed that the transgene was present either as a single copy in lines $R_{1}$ cp 10 and $R_{1}$-cp 11 or as multiple copies in lines $R_{1}$-cp $4, R_{1}$-cp 6 , $\mathrm{R}_{1}$-cp 8, and $\mathrm{R}_{1}$-cp 12 (data not shown). The northern blot analysis performed using tissue from the same plants chosen for the Southern analysis revealed the presence of the transgene transcript, but quantitative differences among the transgenic lines were not evident (Fig. 3). Protein blot analysis performed in resistant plants of lines $\mathrm{R}_{1}$-cp 2, $\mathrm{R}_{1}$-cp 4, $\mathrm{R}_{1}$-cp $6, \mathrm{R}_{1}$-cp $10, \mathrm{R}_{1}$-cp 11 , and $\mathrm{R}_{1}$-cp 12 showed that the transgene protein was not detectable (Fig. 4 ).

\section{DISCUSSION}

The $\mathrm{R}_{1}$ generation of tobacco plants ( $N$. tabacum 'Xanthi') transformed with a binary vector containing the coat protein gene of ToMoV modified by the deletion of 30 nucleotides in the $5^{\prime}$ end exhibited different degrees of resistance to ToMoV infection that included immunity and recovery from the initial onset of the disease. There was a positive correlation between the presence of the transgene and the resistant phenotypes; nevertheless, the correlation was not $100 \%$. In addition, in some cases, the presence of the

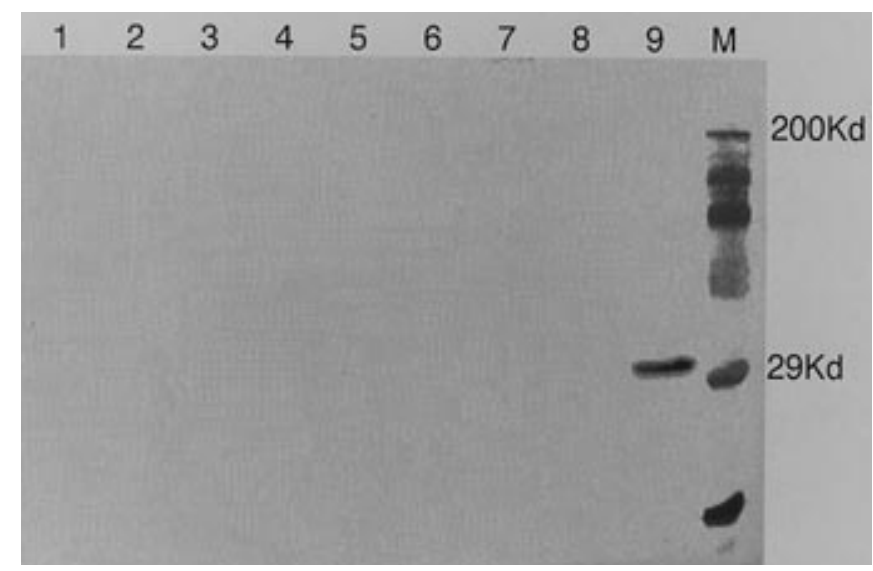

Fig. 4. Protein blot of the immune transgenic tobacco plants tested with a tomato mottle virus (ToMoV) coat protein antibody. Lane 1, healthy control; lanes 2, 3, 4, 5, 6, 7, and 8, selected resistant plants of lines $R_{1}$-cp 2, $R_{1}$-cp 4, $\mathrm{R}_{1}$-cp 6, $\mathrm{R}_{1}$-cp 8, $\mathrm{R}_{1}$-cp $10, \mathrm{R}_{1}$-cp 11 , and $\mathrm{R}_{1}$-cp 12, respectively, showing lack of protein reactivity with the antiserum made against ToMoV coat protein; lane 9, ToMoV-infected tobacco plant; and lane M, molecular weight marker. 
transgene gave rise to infected plants that expressed unusual symptoms (bright vein yellowing phenotype).

The protein product of the transgene was not detected in any of the resistant lines. It is possible that the protein was not detected because it was rapidly cleared from the cell due to an inability to fold and adopt a native conformation as a result of the N-terminal truncation. Lack of cellular retention of the protein due to irregular folding was reported for a truncated form of tobacco etch virus (TEV) coat protein (33). Alternatively, modification of the N-terminus of the ToMoV coat protein could cause the protein to remain in the cytoplasm where there is high proteolytic activity. Kunik et al. (16) showed that the nuclear localization signal of the coat protein of TYLCV, a monopartite whitefly-transmitted geminivirus, mapped to the $\mathrm{N}$-terminus and its deletion would be expected to impair the accumulation of the coat protein in the nuclei. The lack of detection of the transgene product suggests that it may not be involved in eliciting the resistance response.

The only report of engineered resistance to a geminivirus using the coat protein gene was by Kunik et al. (17), which reported that resistance to TYLCV was associated with the presence of the transgene product. Plants in which the transgene product was not detected were susceptible to TYLCV (17).

Viral coat protein genes have been widely used to engineer resistance to RNA viruses. Reports of resistance using full-length nonmodified coat protein genes indicated that resistance was positively correlated to high levels of expression of the transgene $(12,20,28$, $34,35)$. Resistance was expressed as a reduction in symptom severity and virus accumulation. In addition, resistance could be overcome by increasing the dose of inoculum. This contrasts with the resistance obtained from a modified coat protein gene of TEV (32). $N$. tabacum 'Burley' was transformed with the TEV coat protein gene modified by a stop codon near the $3^{\prime}$ end. Though a transgene transcript was detected, the transgene product could not be detected and transformed plants were highly resistant. These results are similar to our observations using a modified ToMoV coat protein gene.

There are numerous reports of genetically engineered resistance responses to RNA viruses. A lack of correlation between resistance and the expression level of the transgene was observed in many of these reports. This type of resistance has been referred to as RNA mediated $(9,19,22,29)$. RNA-mediated resistance is also characterized by a lack of dependence upon inoculum dose and a narrow spectrum of protection. In the current research, resistance responses (recovery and immunity) were observed in transgenic plants subjected to relatively high inoculation levels (continuous inoculation for 15 days by approximately 20 whiteflies per plant). RNA-mediated resistance is often associated with the presence of multiple copies of the transgene or transgene tandem repeats (31), which agrees with our observation that the majority of the transgenic plants exhibiting a resistance response had multiple copies of the transgene.

The lack of correlation between the level of expression of the truncated ToMoV coat protein gene and the resistance response suggests that the resistance may be due to a RNA-mediated mechanism. Studies are underway to address this possibility.

\section{ACKNOWLEDGMENTS}

Florida Agricultural Experiment Station Journal Series No. R-06899. This work was funded, in part, by USDA-CBAG Special Programs Grant No. 92-34135-7456, BARD-US Grant IS 1813-90, and the Florida Tomato Committee. X. H. Sinisterra was holder of a Colombian Institute for the Advancement of Science Scholarship-Loan at the beginning of this research.

\section{LITERATURE CITED}

1. Abouzid, A. M., Polston, J. E., and Hiebert, E. 1992. The nucleotide sequence of tomato mottle geminivirus isolated from tomatoes in Florida. J. Gen. Virol. 73:3225-3229.
2. Beachy, R. N. 1993. Transgenic resistance to plant viruses. Semin. Virol. 4:327-328.

3. Beachy, R. N., Loesch-Fries, S., and Tumer, N. E. 1990. Coat protein resistance against virus infection. Annu. Rev. Phytopathol. 28:451-474.

4. Bendahmane, M., and Gronenborg, B. 1997. Engineering resistance against tomato yellow leaf curl virus using antisense RNA. Plant Mol. Biol. 33:351-357.

5. Briddon, R. W., Pinner, M. S., Stanley, J., and Markham, P. G. 1990. Geminivirus coat protein gene replacement alters insect specificity. Virology 177:85-94.

6. Cancino, M., Abouzid, A. M., Morales, F. J., Purcifull, D. E., Polston, J. E., and Hiebert, E. 1995. Generation and characterization of three monoclonal antibodies useful in detecting and distinguishing bean golden mosaic virus isolates. Phytopathology 85:484-490.

7. Cocciolone, S. M., and Cone, K. C. 1993. P1-Bh, an anthocyanin regulatory gene of maize that leads to variegated pigmentation. Genetics 135: 575-588.

8. Day, A. G., Bejarano, E. R., Buck, K. W., Burrel, M., and Lichenstein, C. P. 1991. Expression of antisense viral gene in transgenic tobacco confers resistance to the DNA virus tomato golden mosaic virus. Proc. Natl. Acad. Sci. U.S.A. 88:6721-6725.

9. Dougherty, W. G., Lindbo, J. A., Smith, H. A., Parks, T. D., Swaney, S., and Proebsting, W. M. 1994. RNA-mediated resistance in transgenic plants: Exploitation of a cellular pathway possibly involved in RNA degradation. Mol. Plant-Microbe Interact. 7:544-552.

10. Duan, Y.-P., Powell, C. A., Webb, S. E., Purcifull, D. E., and Hiebert, E. 1997. Geminivirus resistance in transgenic tobacco expressing mutated BC1 protein. Mol. Plant-Microbe Interact. 10:617-623.

11. Gardiner, W. E., Sunter, G., Brand, L., Elmer, J. S., Rogers, S. G., and Bisaro, D. M. 1988. Genetic analysis of tomato golden mosaic virus: The coat protein is not required for systemic spread or symptom development. EMBO (Eur. Mol. Biol. Organ.) J. 7:899-904.

12. Hemmenway, C., Fang, R.-X., Kanewiski, W. K., Chua, N.-H., and Tumer, N. E. 1988. Analysis of the mechanism of protection in transgenic plants expressing the potato virus $X$ coat protein or its antisense RNA. EMBO (Eur. Mol. Biol. Organ.) J. 7:1273-1280.

13. Hong, Y., and Stanley, J. 1996. Virus resistance in Nicotiana benthamiana conferred by African cassava mosaic virus replication-associated protein (AC1) transgene. Mol. Plant-Microbe Interact. 9:219-225.

14. Horach, R. B., Fry, J. E., Hoffmann, N. L., Waltoth, W., Eichholtz, D., Rogers, S. G., and Fraley, R. T. 1985. A simple and general method for transferring genes into plants. Science 237:1229-1231.

15. Kring, J. B., Schuster, D. J., Price, J. F., and Simone, G. W. 1991. Sweetpotato whitefly-vectored geminivirus on tomato in Florida. Plant Dis. 75:1186.

16. Kunik, T., Karuppaiah, P., Czosnek, H., Citovsky, V., and Gafni, Y. 1998. Nuclear import of tomato yellow leaf curl virus (TYLCV) in plant and insect cells. Plant J. 13:393-399.

17. Kunik, T., Salomon, R., Zamair, D., Zeidan, M., Michelson, I., Gafni, Y., and Czosnek, H. 1994. Transgenic tomato plants expressing the tomato yellow leaf curl virus capsid protein are resistant to the virus. Bio/Technology 12:500-504.

18. Lazarowitz, S. G. 1992. Geminiviruses: Genome structure and gene function. Crit. Rev. Plant Sci. 11:327-349.

19. Lindbo, J. A., and Dougherty, W. G. 1992. Pathogen-derived resistance to a potyvirus: Immune and resistant phenotypes in transgenic tobacco expressing altered forms of a potyvirus coat protein nucleotide sequence. Mol. Plant-Microbe Interact. 5:144-153.

20. Loesch-Fries, L. S., Merlo, D., Zinnen, T., Burhop, L., Hill, K., Krahn, K., Jarvis, N., Nelson, S., and Halk, E. 1987. Expression of alfalfa mosaic virus RNA 4 in transgenic plants confers virus resistance. EMBO (Eur. Mol. Biol. Organ.) J. 6:1845-1851.

21. Lomonossoff, G. P. 1995. Pathogen derived resistance to plant viruses. Annu. Rev. Phytopathol. 33:323-343.

22. Meyer, P., and Saedler, H. 1996. Homology-dependent gene silencing in plants. Annu. Rev. Plant Physiol. Plant Mol. Biol. 47:23-48.

23. Noris, E., Accotto, G. O., Tavazza, R., Brunetti, A., Crespi, S., and Tavazza, M. 1996. Resistance to tomato yellow leaf curl geminivirus in Nicotiana benthamiana plants transformed with a truncated viral $\mathrm{C} 1$ gene. Virology 224:130-138.

24. Pascal, E., Goodlove, P. E., Wu, L. C., and Lazarowitz, S. G. 1993. Transgenic tobacco plants expressing the geminivirus BL1 protein exhibit symptoms of viral disease. Plant Cell 5:795-807.

25. Polston, J. E., Chellemi, D. O., Schuster, D. J., McGovern, R. J., and Stanley, P. A. 1996. Spatial and temporal dynamics of tomato mottle geminivirus and Bemisia tabaci (Genn.) in Florida tomato fields. Plant Dis. 80:1022-1028.

26. Polston, J. E., Hiebert, E., McGovern, R. J., Stansly, P. A., and Schuster, D. J. 1993. Host range of tomato mottle virus, a new geminivirus infecting tomato in Florida. Plant Dis. 77:1181-1184. 
27. Pooma, W., Gillette, W. K., Jeffrey, J. L., and Petty, I. T. D. 1996. Host and viral factors determine the dispensability of coat protein for bipartite geminivirus systemic movement. Virology 218:264-268.

28. Powell Abel, P., Nelson, R. S., De, B., Hoffman, N., Rogers, S. G., Fraley, R. T., and Beachy, R. N. 1986. Delay of disease development in transgenic plants that express the tobacco mosaic virus coat protein gene. Science 232:738-743.

29. Prins, M., and Goldbach, R. 1996. RNA mediated virus resistance in transgenic plants. Arch. Virol. 141:2259-2276.

30. Sandford, J. C., and Johnson, S. A. 1985. The concept of pathogen derived resistance. J. Theor. Biol. 113:395-405.

31. Sijen, T., Wellink, J., Hiriart, J. P., and van Kammen, A. 1996. RNAmediated virus resistance: Role of repeated transgenes and delineation of targeted regions. Plant Cell 8:2277-2294.
32. Silva-Rosales, L., Lindbo, J. A., and Dougherty, G. W. 1994. Analysis of transgenic tobacco plants expressing a truncated form of a potyvirus coat protein nucleotide sequence. Plant Mol. Biol. 24:929-939.

33. Swaney, S., Powers, H., Goodwin, J., Silva Rosales, L., and Dougherty, W. G. 1995. RNA-mediated resistance with nonstructural genes from the tobacco etch virus genome. Mol. Plant-Microbe Interact. 8:1004-1011.

34. Tumer, N. E., O’Connell, K. M., Nelson, R. S., Sanders, P. R., Beachy, R. N., Fraley, R. T., and Shah, D. M. 1987. Expression of alfalfa mosaic virus coat protein gene confers cross-protection in transgenic tobacco and tomato plants. EMBO (Eur. Mol. Biol. Organ.) J. 6:1845-1851.

35. van Dun, C. M. P., Verdium, P., van Vloten-Doting, L., and Bol, J. F. 1988. Transgenic tobacco expressing tobacco streak virus or mutated alfalfa mosaic virus coat protein does not cross protect against alfalfa mosaic virus infection. Virology 164:383-389. 